\title{
The Macroeconomic Repercussions of Agricultural Shocks and their Implications for Insurance
}

\author{
Paul Collier*
}

April 2002

\begin{abstract}
The paper considers the macroeconomic impact of shocks to agricultural output and of negative and positive price shocks. It is shown that negative price shocks have particularly large externalities: it is estimated that the overall impact of these negative shocks on GDP may well be double their direct impact. In terms of policy, the presence of externalities justifies subsidising the provision of insurance. If insurance is not feasible, then foreign aid may be helpful. Turning to other systemic shocks, it is argued that the macroeconomic consequences of negative output shocks are far less important. Positive price shocks also have substantial macroeconomic externalities via their effect on asset demand. Appropriate central bank policy is crucial and requires a detailed understanding of asset demand changes in response to price shocks. Since this may well be unlikely, dollarization may be a better strategy.
\end{abstract}

Keywords: agriculture, price shocks, insurance, price stabilization, dollarization

JEL classification: O13, E30, E58, Q17

Copyright (C) UNU/WIDER 2002

*The World Bank, Washington DC

This study has been prepared within the UNU/WIDER project on Insirance Against Poverty, which is directed by Dr Stefan Dercon.

A previous draft of this paper was presented at the WIDER Workshop 'Insurance against Poverty,' 15-16 June 2001, Helsinki, Finland. The findings, interpretations, and conclusions expressed in this paper are entirely those of the author. They do not necessarily represent the views of the World Bank, its Executive Directors, or the countries they represent.

UNU/WIDER gratefully acknowledges the financial contribution to the project by the Ministry for Foreign Affairs of Finland. 


\section{Acknowledgements}

I would like to thank Tony Addison and Stefan Dercon for comments on a previous draft.

UNU World Institute for Development Economics Research (UNU/WIDER) was established by the United Nations University as its first research and training centre and started work in Helsinki, Finland in 1985. The purpose of the Institute is to undertake applied research and policy analysis on structural changes affecting the developing and transitional economies, to provide a forum for the advocacy of policies leading to robust, equitable and environmentally sustainable growth, and to promote capacity strengthening and training in the field of economic and social policy making. Its work is carried out by staff researchers and visiting scholars in Helsinki and through networks of collaborating scholars and institutions around the world.

UNU World Institute for Development Economics Research (UNU/WIDER)

Katajanokanlaituri 6 B, 00160 Helsinki, Finland

Camera-ready typescript prepared by Jaana Kallioinen at UNU/WIDER

Printed at UNU/WIDER, Helsinki

The views expressed in this publication are those of the author(s). Publication does not imply endorsement by the Institute or the United Nations University, nor by the programme/project sponsors, of any of the views expressed.

ISSN 1609-5774

ISBN 92-9190-214-4 (printed publication)

ISBN 92-9190-215-2 (internet publication) 


\section{Introduction: dissipation versus contagion}

In the microeconomics of agricultural households the distinction between idiosyncratic and systemic shocks is of interest because of their different implications for local insurability. The risks from idiosyncratic shocks can profitably be pooled locally, whereas those from systemic shocks cannot. From the macroeconomic perspective the distinction is, however, even sharper. Idiosyncratic risks, whether insured or not, net out at the aggregate level, whereas systemic risks cumulate and so have macroeconomic effects on consumption and savings. When changes in the demand for consumer goods and assets are sudden and large, they can generate non-pecuniary externalities, which effect output in the rest of the economy. In this case the full impact of systemic agricultural shocks is not confined to producers: the decisions of producers have externalities for other agents. Potentially, these second round repercussions of systemic agricultural shocks are more important than their direct effects. Hence, whereas idiosyncratic shocks are dissipated at the macroeconomic level, systemic shocks are potentially contagious.

Table 1 illustrates the paradox of insurance provision from the perspective of the macroeconomy. Since synchronized shocks are likely to have repercussions for other agents in the economy, the desirable pattern of insurance is for these shocks to be insured, whereas the insurance of idiosyncratic shocks is unimportant. In fact, the economy will generate precisely the opposite pattern: idiosyncratic shocks will be insured, while systemic shocks will be uninsured.

Systemic agricultural shocks obviously occur both for prices and for quantities: world prices for many agricultural products are volatile, and supply at the national level is subject to shocks from climate and disease. However, price shocks are usually more extreme than quantity shocks. Just as idiosyncratic shocks net out when aggregated, so modest systemic agricultural shocks net out against other systemic disturbances. Hence, it is only the large systemic agricultural shocks, which have important macroeconomic effects, and these are mostly generated by price changes rather than by quantity changes. In Section 2, I consider the repercussions of large negative agricultural price shocks. Those price changes that are for agricultural products, which are not traded internationally, generate only transfers between domestic agents. Whether these transfers have a net impact upon consumption and saving depends upon differences in behavioural responses between types of agent and hence on the particularities of each case. Hence, I focus on agricultural exports. Price changes for exports generate a net income effect and so necessarily have an impact on consumption and savings.

Table 1

The paradox of insurance provision

\begin{tabular}{ccc}
\hline & Nature of shock & \\
$(\mathrm{A}=$ actual, $\mathrm{D}=$ desirable $)$ & \\
\hline Insured & Idiosyncratic & Systematic \\
Uninsured & A & $\mathrm{D}$ \\
\hline
\end{tabular}


A fall in the price of agricultural exports gives rise to an income shock to the household, the locality, and the nation. Usually, the income shock will change aggregate demand, but by less than the shock because consumption will be partially cushioned by changes in liquid assets. The fall in aggregate demand potentially causes changes in aggregate supply. The extent of such an effect depends upon the degree of flexibility of prices and initial spare capacity. The Keynesian model assumes fixed prices. With fixed prices negative shocks will reduce output through underemployment and the Keynesian multiplier. If there is initial spare capacity, positive shocks will also affect output in the opposite direction. The neo-classical model assumes fully flexible prices and hence full employment. There will nevertheless be an output multiplier as a result of changes in savings and investment: for example, a windfall will be invested and this will augment subsequent output. In most developing countries, especially in rural areas, prices are highly flexible and there is little spare capacity. However, complete price flexibility in response to large and sudden shocks is unlikely since, in effect, it would imply that information costs were zero. Hence, the actual extent of an output multiplier is an empirical matter.

In Section 3, I turn to positive price shocks for agricultural exports. Large and sudden increases in prices are likely to cause a sharp and temporary increase in the demand for financial assets. However, private agents cannot in aggregate change their net financial asset position without accommodation by the central bank. Hence, inept policy by a central bank can frustrate the asset strategies of private agents. Finally, in Section 4, I briefly consider agricultural quantity shocks.

\section{Macroeconomic repercussions of negative agricultural price shocks}

In work with Jan Dehn (Collier and Dehn 2001) I investigate the extent to which price shocks for primary commodity exports are transmitted onto output. Although we consider all primary commodity exports other than oil, including those which are nonagricultural, the effects of price shocks for agricultural exports are not significantly different from the general pattern. We consider only large annual price shocks defined as price changes, which are in one or other of the 2.5 per cent tails of the frequency distribution of price changes. The sample is for 113 developing countries over the period 1957-97 and is described in Dehn (2000). There are 179 large positive shocks and 99 large negative shocks.

We then analyse the effect of these shocks within the framework of the Burnside-Dollar model of how aid effects growth (Burnside and Dollar 2000). Their analysis is for 56 countries during the period 1970-93, with the period divided into six growth episodes each of four years.

In this Section I consider only the effect of the large negative shocks. Within the Burnside-Dollar sample there are 38 episodes during which there was at least one year of severe negative terms of trade shock (i.e. in the bottom 2.5 per cent tail of the distribution of price shocks). The mean for these severe negative shocks was a fall in the world price of 40 per cent between one year and the next. The mean direct income loss from these price shocks is around 6.8 per cent of GDP, where the income loss is defined as the price change times the prior volume of exports. 
If prices were fully flexible this fall in income would only effect constant price GDP through reduced investment. The change in relative prices would induce some resource reallocation, but measured at constant prices this would only have second order effects on aggregate GDP and indeed even the sign of such second order effects would be ambiguous. ${ }^{1}$ At the other extreme, were prices fixed and the income shock could not be cushioned by dissaving, the change in output would be the familiar Keynesian multiplier of $1 /(1-\mathrm{c}-\mathrm{m})$, times the income shock. For plausible ranges of the marginal propensities to consume (c) and import (m), the likely multiplier would be well in excess of unity.

The price shock can occur in any year of the four-year episode, while the effect on growth is estimated over the entire episode. Hence, any output effects of the price shock are observed both for the year in which it occurs, and for between zero and three further years. The output effects of the typical shock are thus observed for eighteen months beyond the year in which it occurs. We find that the these severe negative price shocks have significant and substantial effects, reducing the growth rate of aggregate output by around 1.4 per cent per annum over the episode. Thus, by the end of the episode output is around 5.6 per cent lower and the total loss of output as a per cent of initial annual income is around 14 per cent. Recalling that the average severe shock in our sample constitutes a loss to the income terms of trade of 6.8 per cent of initial GDP, the pure income shock causes a loss of output of approximately double its own value. Thus the implied multiplier from the initial loss of income to the total loss of income is around three: the economy loses three times is terms of trade loss. Such a large multiplier cannot credibly be fully accounted for by disinvestment. Even if households fully protected consumption, so that investment declined by the full amount of the initial income loss, the capital-output ratio would need to be around unity to generate such a large loss of output over such a short period. An implication is that such price shocks cause contagious reductions in income, presumably at least in part due to less than complete price flexibility. If so, presumably the decline in output is not persistent, although the losses themselves are not recovered.

With such large and rapid output losses resulting from a severe fall in the price of agricultural exports, it is implausible that most of the reduction in output comes from agricultural exports or other output produced by the producers of agricultural exports. A more likely account is that the primary recipients of the income shock reduce their demand for domestically produced goods and that, due to less-than-full price flexibility elsewhere in the economy, this in turn reduces output. In this case the second round fall in output would not reflect an optimal response to relative price changes, but rather would be the result of information failures. The income loss to the society from the price shock would be triple the direct effect of the shock: the direct income loss due to the diminished value of exports, plus double that loss through the induced reduction in output across the economy. Instead of the shock being dissipated, it is contagious.

1 If the constant prices used to measure GDP were those prevailing in the year prior to the price shock then necessarily aggregate output would appear to decline as a result of reallocation, however, in practice constant price GDP is measured at relative prices which prevailed several years prior to the price shock and so the induced resource reallocation could even raise the valuation of aggregate output. 
What can be done to remedy such shocks? Dehn and I explore the effect of compensatory changes in aid inflows. We add an interaction term of the price shock and changes in the aid inflow to the Burnside-Dollar regression. We measure the change in the aid inflow as the average during the four-year period being analysed relative to the average in the preceding four-year period. We find that the interaction term is significant and positive: increased aid offsets the adverse effect on output of a sharp decline in export prices. This approach also constitutes an indirect test of the channels by which the reduction in output is generated. Since aid does not restore the domestic price of the export crop, if the reduction in output were directly a labour supply decision of exporters, then aid would not be able to offset the reduction in output. In fact we find that increases in aid compensate for the effect of the income loss from exports approximately one-for-one. That is, for the average 40 per cent price fall and resulting 6.8 per cent direct decline in income, were donors to increase aid by an equivalent amount to this direct income loss there would be no second round loss of output. Since the Burnside and Dollar growth regression already includes aid as an explanatory variable (and its interaction with policy), the compensatory output effect of aid during negative shocks is over and above its normal effect on growth. Hence, the result is not simply that aid projects are productive. Rather, it shows that precisely at times of falling aggregate demand due to terms of trade losses, additional aid is unusually productive. Since both other effects of aid and the effects of policy are controlled for, the most plausible explanation for this is surely that it is preventing the fall in aggregate demand and thus preventing the adverse output responses to it.

To summarize, we find that large negative export price shocks have two adverse effects on income, a direct effect, which accrues to producers of export goods and an indirect effect of about double the magnitude which presumably accrues to those who supply them with consumer goods. We have found that a temporary increase in aid, of the same order or magnitude as the price shock, will on average fully neutralize the second of these effects. Of course, the aid does not accrue to the producers of exports, it accrues to the government. Thus, while a donor-run insurance scheme providing compensation to the government could fully rectify the contagion-type feature of export price shocks, it would obviously not directly compensate exporters.

The dilemma in providing such a donor insurance arrangement is that, far from directly compensating exporters, a temporary aid inflow would actually amplify the income shock to them despite neutralizing it to the economy as a whole. The reason for this is that aid, like exports, is an inflow of foreign exchange and so tends to appreciate the real exchange rate. Aid competes with exports to supply imports to the rest of the economy. In the absence of compensatory aid, the decline in export revenue will depreciate the real exchange rate. The price of non-tradable goods declines relative to the price of imports. This cushions the decline in the overall purchasing power of exports in units of consumption. The real exchange rate depreciation acts as an automatic insurance mechanism for exporters, passing the income decline on across the society. Because of the depreciation of the real exchange rate, and the second round multiplier effects on output, the structure of risk-bearing from the typical export price shock is complex. Table 2 sets out an estimate in which I assume arbitrarily that due to exchange rate depreciation the initial 6.8 per cent income loss is shared equally between exporters and producers of non-tradable goods. That is, the decline in demand for local goods on the part of exporters lowers the price of those goods sufficiently to cushion half of their income loss, thereby passing it on to the rest of the society. I assume that the second round decline in output of 14 per cent is likely to be concentrated among producers of non-tradable goods who face excess supply. 
Table 2

Distributional effects of negative agricultural export price shocks with and without compensating aid

\begin{tabular}{|c|c|c|c|c|}
\hline & $\begin{array}{l}\text { Fall in export } \\
\text { Price }=6.8 \%\end{array}$ & $\begin{array}{c}\text { Aid }=6.8 \% \\
\text { of GDP }\end{array}$ & $\begin{array}{l}\text { Induced decline } \\
\text { In output }\end{array}$ & Total \\
\hline \multicolumn{5}{|l|}{ Without aid } \\
\hline $\begin{array}{l}\text { Effect on export } \\
\text { producers }\end{array}$ & $-3.4 \%$ & - & 0 & $-3.4 \%$ \\
\hline $\begin{array}{l}\text { Effect on rest of } \\
\text { economy }\end{array}$ & $-3.4 \%$ & - & $-14 \%$ & $-17.4 \%$ \\
\hline Total effect & $-6.8 \%$ & - & $-14 \%$ & $-20.8 \%$ \\
\hline \multicolumn{5}{|l|}{ With aid } \\
\hline $\begin{array}{l}\text { Effect on export } \\
\text { producers }\end{array}$ & $-6.8 \%$ & 0 & 0 & $-6.8 \%$ \\
\hline $\begin{array}{l}\text { Effect on rest of } \\
\text { the economy }\end{array}$ & 0 & $6.8 \%$ & 0 & $+6.8 \%$ \\
\hline Total effect & $-6.8 \%$ & $6.8 \%$ & 0 & 0 \\
\hline
\end{tabular}

Were this shock to be fully compensated by increased aid, there would be no depreciation in the real exchange rate. The structure of risk-bearing would then be that exporters would bear the full 6.8 per cent loss from the terms of trade decline, while those agents who were direct beneficiaries of the aid inflow would gain by an equivalent amount. To heighten the dilemma, in the Table I assume that the beneficiaries of the extra aid are entirely distinct from the producers of agricultural exports. However, this seems quite a reasonable assumption. The only type of aid which could be disbursed sufficiently quickly to compensate for fall in export prices is programme aid: hence donors do not have the time to design and implement additional aid projects targeted at export producers. The government is itself unlikely to be able to target the aid towards export producers and presumably does not even have the incentive to do so.

To summarize the donors' dilemma, compensation to the society is a highly efficient use of aid: aid is atypically productive when it is used to offset negative terms of trade shocks. However, it involves the opposite of insurance for the primary recipients of the shock.

This dilemma was seen in practice in the Stabex scheme of the European Union. The initial version of this scheme provided compensation to governments for periods of low prices of agricultural exports. However, sensitive to the critique that the effects on the real exchange rate were having adverse effects on precisely the farmers who were hit by the price shock, the revised version of the Stabex scheme required that all Stabex aid should be used for projects, which benefited farmers. Inevitably, such projects have very long lead times and so Stabex funds could not be disbursed during the period of the price shock. Indeed, the delays in disbursement were so long that the receipt of funds tended to be pro-cyclical with export prices rather than counter-cyclical. Thus, Stabex sacrificed the aggregate demand compensation effects for which compensatory aid appears to be highly effective. 
What is the way out of this dilemma? One implication is that because negative export price shocks have large externalities beyond their impact on export producers, the producers will under-insure relative to the social optimum. To the extent that export producers do insure locally, they may even make the problem worse. Domestic insurance does not prevent the impact of a terms of trade decline on aggregate income, it simply shifts the income loss to some other agents in the economy. Since the agents to whom the risk is shifted are better placed to bear shocks, the impact upon aggregate demand of a given income shock will be more muted. However, offsetting this, insurance induces farmers to increase their exposure to export price shocks, thereby increasing the exposure of the society. Thus, improved domestic insurance arrangements may increase the need for aid to compensate the rest of the society.

The first best is to supply international insurance for export prices direct with farmers. If farmers could fully insure internationally, the rest of the economy would not suffer the decline in demand when export prices fell and so donors would not need to compensate. Hence, donors could potentially justify subsidizing such an insurance arrangement to try to offset the externalities generated when exporters suffer income losses. However, any scheme which is more generous than is actuarially justified raises the overall return to export production and thereby involves moral hazard: producers will increase output. Donors can, however, cover the administrative costs of an insurance scheme without encountering moral hazard. A scheme established without donor assistance would need to be self-financing, covering its own administrative costs. To recover these costs, the prices paid to farmers would on average need to be below prices without insurance. Hence, the insurance scheme would lower the mathematical expectation of the producer price. The avoidance of moral hazard only requires that the expected price should not be increased by the scheme. As the Grameen Bank credit schemes have shown, while poor people are willing to take up and repay credit at significantly positive interest rates, the administrative costs of such schemes are very high. It is sometimes argued that if these schemes can be self-financing, subsidy of administrative costs is unnecessary, whereas if the schemes cannot be self-financing, subsidy of administrative costs is unjustified: the cost to donors exceeds the value to users. However, in the case of crop price insurance, the private benefits to the producer appear very substantially to understate the social benefits. Hence, where price insurance is unviable without donor subsidy of administrative costs, even though the cost to donors will exceed the direct cost to users, they may still be justified by the large external benefits to society. Indeed, in the presence of such an externality, even where a price insurance scheme is viable without subsidy, producers will not insure to the extent that is socially efficient, and so subsidy of administrative costs is desirable.

In the absence of international insurance direct to producers, domestic insurance of export prices for producers can be combined with international insurance direct to the government. The domestic insurance spreads the shock across the society, and the international insurance to the government then prevents the aggregate demand decline. Note that international subsidy of domestic insurance arrangements does not provide the necessary neutralization of the aggregate demand shock: the insurance has to be external. A third best is for international insurance of the government, combined with domestic insurance of farmers more generally, although not targeted to export prices. 


\section{Macroeconomic repercussions of positive agricultural price shocks}

For idiosyncratic shocks, whether positive or negative, agents can cushion consumption by using community insurance and credit arrangements, as well as by accumulating and decumulating assets. However, for shocks which are systemic at the national level, such as export price shocks, national or sub-national level insurance is not feasible and so the society must rely upon asset accumulation and decumulation. This introduces a potential asymmetry in responses to positive and negative shocks. Agents may individually choose to accumulate assets, but they can only decumulate to the extent that they already hold assets in liquid form. The holding of large liquid balances is costly and is likely to be unnecessary to guard against idiosyncratic shocks, which are a great deal more common than systemic shocks. Hence, we would expect that unlike idiosyncratic shocks, systemic shocks would produce asymmetric effects depending upon whether they were positive or negative. Large positive shocks would disproportionately induce asset accumulation, whereas large negative shocks would necessarily have to be absorbed predominantly by reductions in consumption.

In the short term, the increased demand for assets would predominantly take the form of financial assets: the acquisition of real assets requires time both to plan investments and to implement them. Hence, this asymmetry would be manifest in the impact on aggregate demand: large negative shocks would reduce demand more than large positive shocks would increase them. In Section 2, I investigated the multiplier from large negative shocks: the typical negative shock reduced output by twice the decline in initial income, and I interpreted this as evidence for powerful Keynesian-type effects on aggregate demand. Dehn and I also investigate the effects of large positive shocks. The typical positive shock is even larger than the typical negative shock - the mean price increase is of 47 per cent as compared with the mean price decrease of 40 per cent. Further, as might be expected from the basic theory of commodity price determination (Deaton and Laroque 1992), there are more large positive shocks than large negative shocks. Despite the fact that the positive shocks are both larger and more numerous, we find that they have no significant effects, positive or negative, on short-term growth. Whereas large negative shocks severely reduce output, large positive shocks do not increase it. This asymmetry has two interpretations consistent with the Keynesian aggregate demand story proposed for negative shocks. First, it might be that the economy is normally operating at full employment of resources, so that increases in aggregate demand simply translate into higher prices rather than additional output. Second, it might be that savings rates out of positive shocks are sufficiently high that the demand effects are quite modest.

Both of these interpretations might be correct. There is considerable microeconomic evidence that farmers have high savings rates out of agricultural price windfalls (Collier, Gunning and Associates 1999), commonly around or even above 50 per cent. Such high dissaving rates from large negative windfalls are implausible simply because they would require poor people to hold very large liquid assets. Hence, the aggregate demand shock from large price increases might indeed be considerably smaller than from price decreases. These more modest aggregate demand shocks might then have less impact on output because the economy is normally close to full utilization of resources. 
I will assume that the high savings rate from positive windfalls is at least part of the story of such shocks. I now turn to the consequences of this sudden increase in the demand for assets.

First, consider the effect of a large increase in the world price of the export crop in a fully dollarized economy. Typically, there are large wedges between borrowing and lending rates in the financial markets to which small farmers have access. As a result, we would expect the increased savings should in the medium term translate predominantly into an increase in productive assets in the enterprises in which the farmer is engaged, rather than an accumulation of financial assets. Yet in the short term such an increase in real assets will usually not be feasible. Time will be needed, both to assess the overall scale of the windfall, and to identify and implement investment plans. During this interval, windfall income must be accumulated in financial assets. In a dollarized economy, these financial assets will, by definition, be foreign assets. As each farmer accumulates financial assets, the economy as a whole accumulates claims abroad. During this period, the holdings of dollars in the economy will increase both absolutely and relatively to income. Conversely, when farmers reach the phase of implementing their investment plans, they will convert these financial assets into real assets and so dollar holdings in the economy will decline again. In such a dollarized economy, an export price boom therefore induces temporary changes in the aggregate demand for real money balances, which are automatically satisfied by the accumulation and decumulation of dollar holdings.

However, very few economies are fully dollarized. Many small, low-income countries have their own currencies with floating exchange rates against the dollar, but very limited markets in domestic debt. Central banks can intervene in the foreign exchange market, but cannot offset such interventions by transactions in domestic bond markets. Hence, they cannot effectively sterilize changes in the money supply brought about by their exchange rate interventions. These central banks nevertheless operate with a policy rule on monetary growth. A common policy rule, under arrangements with the IMF, is for the nominal money supply to be subject to a ceiling rate of increase. In the circumstances of an export price boom, such ceilings create a divergence between individual and aggregate asset behaviour. To see this, consider what happens if the demand for real money balances, necessarily in domestic currency, rises as a result of the shock by more than the increase permitted by the agreed ceiling. Exporters initially receive additional dollars, which they attempt in aggregate to convert into additional domestic currency. The central bank refuses to make net purchases of foreign currency because this would increase the domestic money supply beyond the ceiling. As a result, the domestic currency appreciates sharply against the dollar. This appreciation in turn lowers the price level: the nominal domestic currency price of importable goods falls. In turn, the decline in the price level brings about the desired increase in real money balances and, indeed, this is the point at which the exchange rate ceases to appreciate.

Such a rapid and dramatic sequence of events can be seen in the Ugandan coffee boom of 1994, the result of a frost in Brazil which damaged the Brazilian coffee crop and approximately tripled the world price. The increase in the world price of coffee was very largely passed on to coffee farmers. Since this was the first windfall for coffee farmers in almost twenty years it was recognized as exceptional and farmers saved accordingly. The Ugandan economy had a floating exchange rate, virtually no domestic bond market, and ceilings for monetary growth: hence it had precisely the combination of shocks, markets and policy rules discussed above. Within five months of the start of 
the coffee boom the exchange rate had strongly appreciated and the price level had declined absolutely by 6 per cent, reversing an inflation rate which over the previous twelve months had been 16 per cent.

For the central bank to accommodate the increased demand of farmers for real money balances requires an equivalent increase in base money (M0). Increases in 'inside money' net out in aggregate as claims and liabilities: only base money is a net claim of private agents on the government. In turn, to be able to honour these claims, the government, through its central bank, must accumulate foreign financial assets. The increase in base money may itself trigger a much larger increase in bank lending and this could be inflationary. Ideally, the central bank should accommodate the desired increase in base money, but restrain credit expansion by raising the minimum cash ratio that banks must retain.

In Uganda fear of increasing base money was influential in the decision to introduce a windfall export tax on coffee. Such a tax was doubly problematic. First, coffee farmers were even poorer than the average Ugandan, so that the tax was regressive. Secondly, coffee farmers had a high savings and investment rate from that part of the windfall, which they retained, and in retrospect this investment proved to be highly productive. Hence, the tax reduced the scale of the largest investment episode, which rural Uganda has ever experienced. Fortunately, the Ugandan government rapidly repealed the tax and expanded the nominal money supply. Overall during the first year of the boom the money supply in real terms grew by 23 per cent.

Up to this stage, it is of no consequence whether the accumulation of real money balances is directly in dollars, as in a dollarized economy, or in domestic currency as in Uganda. However, in the remain stage of asset responses the difference can be crucial. Recall that in this second stage farmers convert their financial assets into real assets. For an individual farmer it evidently makes no difference whether the money which he converts into real investment, is in dollars or domestic currency. The farmer simply buys the investment goods. However, in aggregate, if the financial asset which farmers are reducing is domestic currency, the outcome will only be a rise in the price level unless the central bank offsets the fall in demand for domestic currency by intervening in the foreign exchange market to sell dollars. In the absence of such intervention farmers achieve their desired decline in real money balances not by converting them into real assets, but by an erosion in the real value of their nominal balances. In this event, the behaviour of farmers in aggregate frustrates their individual intentions: each asset switching decision inflicts a negative externality on others, because the economy in aggregate does not have the resources to expand investment. Precisely this phenomenon occurred in the wake of the cocoa boom in Ghana (Wetzel 1999). Cocoa farmers had a very high financial savings rate out of the windfall but these savings were entirely dissipated by post-windfall inflation. Their windfall was taxed at 100 per cent, not by a direct export tax on cocoa, but by a post-windfall inflation tax.

The key behaviour is thus that of the central bank. Whereas in a dollar economy farmers automatically increase and then run down foreign financial assets, a domestic currency introduces a dual decision problem. The central bank must accumulate and then decumulate dollars to correspond to the changing demand by farmers for domestic currency. The demand for financial assets can change substantially, first upwards and then downwards. The lag between accumulation and decumulation is not necessarily 
related to the length of the windfall: decumulation may precede or occur after the end of the windfall. Rather, it may be related to the necessary lag for farmers to plan and implement substantial investments. Since these lags are not known, the central bank does not know either how much foreign exchange to accumulate, nor when to switch interventions to decumulation. If the central bank fails to accumulate enough foreign assets, or delays running them down, farmers' investment plans cannot in aggregate be fully implemented.

As is evident, were the central bank to stick to a pre-shock ceiling for nominal monetary growth it would completely frustrate farmers' plans. There is, however, a policy rule, which if the central bank follows, will enable farmers to fulfil their plans. This is to maintain an inflation rate, or price level, target rather than a money supply target. In order to keep to a price level target the central bank will need to offset changes in money demand with changes in supply, achieved through interventions in the foreign exchange market. Price level targeting rather than money supply targeting is often discouraged, for good reason. The timeliness and quality of information available to the central bank about changes in the price level is usually inferior to that on changes in the money supply. Money supply figures can be known with very little delay and a high degree of accuracy. Price level information depends upon an administratively complex data gathering system and an aggregation procedure which between them introduce a range of uncertainty. If the data collection system is slow and the aggregation procedure weak, then short-term observed changes in prices have doubtful information content and so are unreliable as the basis for policy. However, at times of agricultural price shocks, targeting the money supply, no matter how accurately it can be observed, are simply an inappropriate policy rule. The correct strategy is therefore to recognize that in economies subject to agricultural price shocks it is important to have a reliable consumer price index. The Ugandan authorities recognized that in their economy the demand for money was unlikely to be stable, so that price level targeting was necessary, and for this they developed both fast collection of raw price data, and reliable aggregation based upon an up-to-date consumer expenditure survey. The consumer price index was available by the end of each month based on prices observed during the middle of the month.

While a central bank operating price-level targeting should correctly accommodate farmers' changing demand for real money balances, in practice central banks are subject to many countervailing pressures. The advice of international agencies and the demands of politicians may from time to time derail a price-level rule. Farmers accumulation of windfall financial savings is likely to depend upon their confidence in financial assets. A good way, and conceivably the only way, for the government to credibly pre-commit to the maintenance of the real value of windfall savings is to dollarize. Small economies, subject to agricultural price shocks should probably not have their own currencies.

Note that this conclusion is at variance with the traditional open economy macroeconomic literature on exchange rates and shocks. In that literature, a flexible exchange rate is preferable to a fixed exchange rate, and a fortiori to dollarization, because it permits price level stabilization during a boom. The rise in the relative price of non-tradables, 'Dutch disease', can be accommodated without an increase in the price level, by a fall in the nominal price of tradables through exchange rate appreciation. However, this analysis is entirely static. It was designed to analyse a once-and-for-all 
shock such as the rise in the price of oil in the mid-1970s. Agricultural price shocks are seldom of this nature. More commonly, they have a strong temporal element: producers respond by saving windfalls as if they viewed such windfalls as liable to be temporary. Hence, the main macroeconomic effects of positive agricultural price shocks are on asset demand rather than on the relative prices of consumer goods. A dollarized economy is disadvantageous if the main effects are in consumer markets, but is advantageous if the main effects are in asset markets.

\section{Macroeconomic repercussions of agricultural output shocks}

In work with Arne Bigsten (Bigsten and Collier 1995) I investigated the effect of agricultural quantity shocks on other sectors of the economy using time series for Kenya. Our proxy measure for output shocks was variations in national agricultural value added measured at constant prices. While value-added and gross output series potentially need not be closely related, in view of the rules of thumb adopted in the Kenyan national accounts, the two series are likely to be very similar. We found that shocks to agricultural value added had no effect on output in other sectors of the economy - with one exception. Output of the construction sector varied pro-cyclically with agricultural output. Further, a Granger causality test established that causality ran from agriculture to construction. A one per cent increase in agricultural value added increased construction value added by 0.8 per cent. Since agricultural value added was considerably larger than construction value added, this converted into an investment rate into construction value added of around 20 per cent. However, note that construction value added is only a proportion of construction expenditure, so that the true investment rate would have been somewhat higher. This is consistent with the evidence that farmers invest windfalls. However, the absence of an effect on the rest of the economy suggests that, at least in Kenya, quantity shocks were not as important as price shocks. None of the negative value-added shocks were as large as the price shocks analysed in Section 2. Outside the Sahel it may be that output shocks are simply less important at the systemic level than price shocks, although they are presumably far more important at the idiosyncratic level.

A second piece of evidence on the effects of quantity shocks is the series of studies of rural Asia by Peter Hazell. He indeed found evidence of a larger multiplier from agricultural income onto the local non-agricultural economy (see Rosengrant and Hazell 2000 , p.108). On average, an increase in agricultural income raised non-agricultural income by between 50 per cent and 100 per cent of the initial increase. However, Hazell was not investigating temporary deviations from the path of growth of agricultural output, but rather permanent large increases in output. Hence, we would expect a smaller proportion of the income gains to be saved, so that they would have a larger impact on aggregate demand in the rest of the economy. Hazell's work is not, therefore, pertinent for arguments concerning risk and insurance. 


\section{Conclusion}

I have looked at three types of systemic agricultural shock: negative price shocks, positive price shocks and output shocks. Export price shocks are intrinsically systemic and so have macroeconomic repercussions: I have cited evidence that when price shocks are extreme, these repercussions are highly adverse. The negative externality created by farmers' aggregate response could be offset were farmers to take out international insurance. The paradox of insurance provision is that farmers are far more likely to insure idiosyncratic shocks than systemic shocks. Idiosyncratic shocks are more common, and local informal and even private formal insurance arrangements are radically more feasible. Hence, to the extent that macroeconomic considerations matter, public insurance provision should concentrate upon export price shocks rather than on quantity shocks. However, macroeconomic considerations are only part of the picture. Indeed, in conventional analyses of farmer insurance they do not even make it into the picture. The usual case for public insurance rests partly on the growth-sacrificing measures that farmers otherwise adopt to reduce risk, and partly on the humanitarian need to target resources to people during transient adverse shocks. Such insurance rightly focuses on quantity shocks. My point is not to call into question the importance of public insurance for quantity shocks, but rather to raise the question of whether price insurance can be made feasible by a modest level of subsidy of administrative costs that thereby does not create moral hazard. If such insurance is feasible, it would be useful because it is price shocks where the large externalities are to be found. To the extent that it is not feasible, it is better to provide the insurance to the economy as a whole, through temporary reallocations of aid, than to leave it uncompensated. I have suggested that concerns that such compensating aid would further hurt export farmers through Dutch disease are probably exaggerated: the costs of the terms of trade shock are large and probably spread widely over the economy. It is more important to reduce these costs than to compensate export farmers themselves.

Negative price shocks appear to have very large externalities, around double their direct effects. Hence, there is a strong case for subsidizing insurance arrangements, subject to the avoidance of moral hazard considerations. Positive price shocks do not create large externalities for aggregate output, but farmers themselves have high savings rates and so use the opportunities well to the extent that macroeconomic policy permits. Hence, income stabilization through government price smoothing appears highly undesirable. Farmers need insurance from negative shocks for the sake of the macroeconomy, whether or not they need it for themselves. By contrast, it is the government, which usually needs to be protected from positive shocks since windfall revenue often destabilizes the budget. While positive shocks retained by farmers do not create large externalities for the rest of the economy, they do often create large externalities among farmers themselves. As each individual farmer saves and dissaves in financial assets, there is a danger that in aggregate they will generate changes in the price level, which neutralize their efforts. To avoid this damaging externality requires that the central bank really understands how to accommodate farmers' rapidly changing asset demands. Since this is quite unlikely, a better strategy might be for the government to dollarize. 


\section{References}

Bigsten, Arne and Paul Collier (1995), 'Linkages from Agricultural Growth in Kenya', in John Mellor (ed.), Agriculture on the Road to Industrialization, IPFRI, Washington DC.

Collier, Paul and Jan Dehn (2001), 'Aid, Shocks and Growth', Policy Research Working Paper 2688, World Bank, Washington DC.

Collier, Paul, Jan Willem Gunning and Associates (1999), Trade Shocks in Developing Countries, Clarendon Press, Oxford.

Burnside, Craig and David Dollar (2000), 'Aid, Policies and Growth', American Economic Review, Vol.90, No.4, pp. 847-68.

Deaton, A. and G. Laroque (1992), 'On the Behaviour of Commodity Prices', The Review of Economic Studies, Vol.59, No.1, pp. 1-23.

Dehn, Jan (2000), 'Commodity Price Uncertainty and Shocks: Implications for Investment and Growth', D.Phil. Thesis Oxford University, December, pp. 232.

Rosegrant, Mark W. and Peter B. R. Hazell (2000), Transforming the Rural Asian Economy: The Unfinished Revolution, Oxford University Press, Hong Kong.

Wetzel, Deborah (1999), 'The Ghanaian Cocoa Boom' in Collier, Gunning and Associates. 